\title{
Intersectoral approach to the legal regulation of corporate conflicts in modern Russia: theory and practice
}

\author{
Anatoly Levushkin ${ }^{1,2,3,4, *}$ and Antonina Golysheva ${ }^{1}$ \\ ${ }^{1}$ Moscow Region State University, 10A, Radio str, 105005, Moscow, Russia \\ ${ }^{2}$ Ulyanovsk state University, 42, Leo Tostoy Street, 432017, Ulyanovsk, Russia \\ ${ }^{3}$ Kutafin Moscow State Law University (MSAL), 9, Sadovaya-Kudrunskaya Str., 125993, Moscow, \\ Russia \\ ${ }^{4}$ Russian state University of justice, 69, Novocheremushkinskaya str., 117418, Moscow, Russia
}

\begin{abstract}
Today, any corporate conflict is a phenomenon that disorganizes the company, which leads to increased uncertainty and often hinders constructive development. Because of the disparate interests of the conflicting parties, a corporate conflict can cause significant damage to the company, which is manifested in both direct losses and missed opportunities. The outcome of the fight for corporate control largely depends on the content of the constituent documents and the provisions of the company's internal documents. At all times and in any business organization, there is an obvious or potential (hidden) conflict of interest between individuals whose contributions affect the effectiveness of such an organization. This determines the increased interest in the research topic of this article. The article analyzes the features of cross-industry legal regulation of corporate conflicts in modern Russia. Theoretical and practical problems and controversial issues of law enforcement are identified.
\end{abstract}

\section{Introduction}

Relevance of research. Legal entities play a special role in the life of modern society. Being the legal form of collective participation of individuals in civil circulation, the legal entity institution allows the flexible use of capital in entrepreneurial activity [1].

The determination of the legal nature and trends of a cross-industry approach to the legal regulation of corporate conflicts is currently the most controversial and fundamental issue of importance for law enforcement corporate activities, especially in relation to large corporations. Studying them is not only necessary from the point of view of the corporate and business law doctrine, but also is of significant practical value, since the legal content of actions to resolve corporate disputes depends on its correct understanding and qualification.

\footnotetext{
*Corresponding author: lewuskin@mail.ru
} 
The research subject is social relations, emerging when applying a cross-industry approach to the legal regulation of corporate conflicts in modern Russia, studying the theory and implementation practice.

Goals/objectives. The goal of the research is a legal analysis of some trends in implementing the cross-industry approach to the legal regulation of corporate conflicts in modern Russia in law enforcement. The methods of resolving conflicts are also studied, which are based on studying the materials of judicial arbitration practice in modern economic and corporate reality in the Russian Federation.

\section{Materials and Methods}

The methodological base of the research is the number of general scientific cognition methods for legal phenomena, such as synthesis, the method of analogy, formal logic, and others. Moreover, specific scientific methods of studying the cross-industry approach to the legal regulation of corporate conflicts in modern Russia and their resolution ways were also taken into account.

It is necessary to clearly realize that the legal entity's activities, stipulated by law and its constituent document, are possible subject to a set of methods for resolving potential conflicts and conscientious behavior of participants in corporate legal relations. At the same time, the possibilities for abuse of rights, including corporate rights, have expanded sufficiently in connection with the development of the market and the information sphere. This requires the prompt development of measures to protect corporate rights and obligations.

"One of the main development trends in both modern scientific knowledge in general and legal science in particular is using the systematic approach in studying the nature of the studied phenomena. It is necessary to pay attention to establishing the cross-industry links between civil, corporate, family and business relations" [2]. The labor relations are of great importance as well.

\section{Results}

"Business activity, being a type of economic activity, includes the organization, support, management and direct implementation of production" [3]. The need for interaction between the state and business is being discussed for a long time already [4]. It seems that the legislator's priority goal in the field of corporate law is to develop various measures and methods that, while being implemented, will most quickly resolve all disagreements between the parties without bringing the conflict to court.

It is quite true that "the means of legal impact on the legal subject's behavior is a legal norm, which forms a model of desirable and undesirable behavior for the subject, a model of his activity in the legal relationship. In other words, in order to achieve a legal result, the action of the legal subject is necessary ... individual legal forms are nothing but the legal form of activity of the legal subject" [5].

Subsequently after the violation of corporate rights, a corporate conflict arises. This is an obvious or potential (hidden) conflict of interests (active or expressed in inaction). The participants of the conflict are persons, whose interests conflict with the interests of a legal entity and (or) participant (participants, members, shareholders, persons working under an employment contract, etc.) of this legal entity on their own initiative or involuntarily and their protection is impossible without entering into such a confrontation.

A sign of a corporate conflict may be a tense atmosphere in the company and, as a result, inefficient work of employees. 
One of the reasons for corporate conflicts is the lack of an effective mechanism for holding managers accountable. Judicial practice in this area did not follow the path of applying the provisions of Article 71 of the Federal Law on JSCs and article 44 of the Federal Law on LLCs.

Furthermore, the occurrence of conflicts in a legal entity is caused by the lack of internal control over the corporate management state of the company. For example, the problem here is the need to create an audit commission in a joint-stock company. As confirmed by the research, strengthening the status of the audit commission in a joint-stock company and expanding its terms of reference can help preventing corporate conflicts. The conflicts usually are caused by various frauds from the side of the management team of the joint-stock company.

A.V. Gabov, O.V. Gutnikov et al. in their monograph [6] divide the possible corporate conflicts participants into the following groups: founders of a legal entity, members of governing bodies, employees of a legal entity, who have labor relations with it, and creditors. At the same time, the above mentioned researchers emphasize that the independent interest of these persons corresponds to the goals of the legal entity. However, at some point interests of persons intersect with goals, and in this connection it becomes impossible to obtain benefits. At the same time, the problem of protecting one's rights and interests arises.

In order to protect corporate rights, the legislator also identifies special protection methods. At the international legal level, there is regulation of civil relations, entrepreneurial activity, relations with the participation of public institutions, state bodies. Relations regarding security and protecting the property rights of the Russian Federation have the widest application at the international level. It is of even greater importance considering the so-called sanctions of foreign states currently applied to the Russian Federation, which are mainly discriminatory in relation to Russia [5]. In practice, universal methods of protecting civil rights are traditionally implemented.

From the point of view of universal protection methods listed in Article 12 of the Civil Code of the Russian Federation, corporate legal measures can determine the contestation of a transaction. The following procedures can be determined as well: exclusion from the membership of a legal entity; voluntary withdrawal of a legal entity from membership; recovery of losses; restoration of the original situation; suppression of actions that infringe rights or may violate them; restoration of corporate control; collection of fine, interest, etc.

Special corporate methods include selling the shares in the manner prescribed by law; transferring the rights and obligations of buyers of shares to the holder of a specific right for first redemption; redemption of the organization's shares on an inherent basis by the shareholder's request; withdrawal from the organization; cancellation of decisions by the governing bodies of organizations in the field of corporate relations and other persons.

One of the ways to minimize risks of a corporate conflict is a corporate contract. "Indeed, throughout the legislation reform regulating entrepreneurial and commercial relations, rules on several new special contractual entrepreneurial structures appeared. In law enforcement, certain results of the law of liability reform aimed at applying special treaties are obvious. These contractual designs allow determining the standard terms and conditions included in the content of the contracts, establishing general rules for contractual cooperation between the parties in the future. There are difficulties in qualifying a number of property and organizational contracts and determining their legal nature" [4,5]. This statement can be fully attributed to corporate contracts.

Implementing the norms on a particular type of business agreement (a group of norms on the corresponding type) is possible only to those agreements, for the regulation of which they are intended. A different approach often leads to the case when a contract of one type is chosen, and the consequences that the counterparty pursued were in another contract [5]. 
Thus, the corporate law in 2014 underwent a reform, as a result of which the number of dispositive norms governing the activities of limited liability companies and non-public joint-stock companies increased significantly. In theory and practice it is justified by the developing role of such a civil law principle as freedom of contract. In turn, it served as fertile ground for the breeding of deadlocks in the process of carrying out economic activities.

This is explained by the fact that directly growing possibility of discretion to consolidate certain provisions by subjects of corporate legal relations leads to a similar increase in the ability to impede the normal functioning of a legal entity, in particular, deadlock.

The law contains several mechanisms for resolving deadlocks: exclusion of a participant from a limited liability company (Article 10 of the Federal Law on LLC); exclusion of shareholder from a non-public joint-stock company (paragraph 4, Part 1, Article 67 of the Civil Code of the Russian Federation); forced liquidation of a legal entity via the lawsuit from corporation participant when it is impossible to achieve the goals, for which the legal entity was created (clause 5, part 3, article 61 of the Civil Code of the Russian Federation). At the same time, other ways to escape the deadlock are suggested in the scientific doctrine and judicial practice, for example, compulsory reorganization by a court decision.

In order to assess the effectiveness of the above mentioned mechanisms, the judicial practice needs to be considered.

So, the exclusion of a participant from members of the legal entity is a specific way of eliminating deadlock (Article 10 of the Federal Law on LLC; paragraph 4, Part 1, Article 67 of the Civil Code of the Russian Federation). According to the legal theory, this measure serves two following purposes: 1) as a result of the implementing such sanction, punishment for the guilty behavior of a member of a legal entity is carried out; 2) in limited liability companies and non-public joint-stock companies, this method justifies itself and leads to the resolution of deadlock due to the fact that the expelled participant cannot influence the resolution of issues. This greatly facilitates the task of the other participant and, in the absence of disagreement, the governing body can finally find an effective solution to a problem that has arisen, or to a problem that arose in the course of the company's activities.

This mechanism is also popular in the judicial practice, in particular, it is widely implemented at the level of the highest courts of the Russian Federation.

Thus, the right to demand exclusion of a person who grossly violates obligations by own actions (inaction) that makes it impossible to carry out activities or substantially complicates it, is held by participants in a limited liability company, whose shares in the aggregate are at least $10 \%$.

The Supreme Court of the Russian Federation [7] ruled that gross violations of duties may include systematic evasion from participating in general meeting of company members without reasonable excuse. It can also be the performance of actions by the participant, which are contrary to the interests of the company, if these actions caused substantial harm to the company and (or) prohibited company activities or substantially hampered them.

However, a lawsuit to exclude a participant from the membership of a company cannot be filed by a person, who also has grounds for exclusion.

Furthermore, it is impossible to exclude a participant of a limited liability company if he/she owns more than half of the total share of the company and if, in accordance with the constituent document of the company, members of the company are free to leave the company.

However, an exclusion is not possible, if the person who has the grounds for exclusion has filed a lawsuit for it [7]. It is also impossible to exclude a participant with a share in the amount of more than $50 \%$ in case when, in accordance with its charter, members of the 
company have the right to freely leave the company (Article 26 of the Federal Law on LLC, clause 11 of the information letter of the Presidium of the Supreme Arbitration Court of the Russian Federation dated 05.24.2012 No. 151 "Review of the practice of consideration by arbitration courts of disputes related to the exclusion of a participant from a limited liability company"). This reflects the principle of the inviolability of the majority in case of a deadlock.

As the Supreme Court of the Russian Federation reasonably explains, far from any conflict situation can become the basis for satisfying a claim of a participant for company liquidation.

The court will satisfy the demand for liquidation only if all other methods of resolving the situation have been exhausted during a prolonged corporate conflict with repeated significant abuses by the participants of the entity. Other methods of resolving the conflict include, for example, exclusion of a legal entity participant, voluntary withdrawal from the company, election of a new person exercising the powers of the sole executive body, etc. [7]

One of the least radical ways to resolve a deadlock can be called the reorganization of entity in the form of separation. The reorganization procedure requires the adoption of unanimous decisions and coordinated actions of all participants in the company. Meanwhile, it is the latter that is often impossible in a company with a serious corporate conflict, which led to a deadlock on a particular issue. Special legislation provides for a sufficiently high quorum for deciding on a reorganization. The qualified majority for jointstock companies is at least $3 / 4 \%$ of the votes (clause 2 of part 1 of article 48 , clause 3,4 of part 49 of the Federal Law on JSCs) and unanimity for limited liability companies (clause 11, part 2 of article 33; paragraph 2, clause 8 of article 37 of the Federal Law on LLCs).

It seems that such situation could be resolved by the institution of forced reorganization by a court decision. At the same time, the Civil Code of the Russian Federation does not directly state the grounds for compulsory reorganization, limiting itself to a special law. Such a mechanism may have several advantages in terms of its potential flexibility. Thus, conflicting participants of a legal entity can get into different legal entities. This will resolve the conflict by preserving the previously existing single legal entity and will not cause damage to the stability of economic turnover due to the fact of universal succession.

Meanwhile, such mechanism for resolving the deadlock situation is rarely used in practice. Even if it is implemented, it is recognized by the courts as not complying with the law. Thus, the plaintiffs, who are participants of a limited liability company, asked the court to reorganize the limited liability company and divide it into two new legal entities. Plaintiffs referred to the impossibility of continuing joint activities with current set of participants as a result of a corporate conflict. The courts of the first and appeal instances refused to satisfy the claims, citing the absence of such compulsory reorganization case as the entity corporate conflict in the law (Federal Law on LLCs) [8].

\section{Discussion}

All methods of protecting corporate rights have certain advantages and disadvantages. When applying a particular method, it is worthwhile to be guided by the actual circumstances and possible means (legal, moral, financial) of a person who is infringed on his rights. Each situation is heterogeneous, its resolution depends on many factors, in particular on the identity of the conflicting parties, the professionalism of their representatives or intermediaries, the price of the disputed asset and other circumstances.

Business is a whole "universe" with its own rules and laws. Often it's organization dictates harsh conditions and an entrepreneur is unreasonable in approaching the goals under stress, sets erroneous objectives. At the same time, the existence of a corporation 
should not be aimed only at the resolution of mutual disagreements, since this is an association of persons created to achieve certain goals. It should be noted that "until now, the market and family economies have not been considered as an alternative resource for the entrepreneurship development in Russia. The transition to market relations has led to an increase in unemployment ..." [9]. Corporate disputes are very common in modern Russia.

As can be noted, untimely response to a conflict situation, which has developed within a legal entity, or its ignoring leads to litigation, to the emergence of a corporate dispute.

Deadlock is characterized by the absence of the ability to carry out the corporation activities, including the organizational and managerial issues being resolved within the company. It is caused by the diverse, sometimes conflicting positions regarding legal entity management cases. The impossibility of reaching agreement on the solution of certain issues arising in the course of the legal entity's activity is a common feature of deadlock.

Such serious conflicts appear in those legal entities, where the general meeting of participants or another governing body consists of two members. Therefore, deadlocks are especially common for limited liability companies and non-public joint-stock companies.

Equal distribution of shares between corporate conflict parties is not an unconditional basis for refusing a lawsuit to expel a participant from a limited liability company. The court has to evaluate the violations of not only the excluded participant, but also the violations made by each participant in the legal entity. This is performed in order to prevent the abuse of the right by these entities, as well as to analyze the adverse consequences arising from violations for a particular limited liability company and only then resolve the dispute [10].

The mediation of the deadlock situation in case of disagreement between the legal entity participants (members, shareholders, etc.) is to a lesser extent caused by the disagreements of the company members themselves then by the reluctance to resolve the disagreements arising. For example, it can be exposed by systematically ignoring visits to general meetings of the company, as well as avoiding participation in them.

At the same time, judicial practice does not define the criteria for such systematicity, pointing, for example, to insufficient evasion of two general meetings [11]. In addition, it is also heterogeneous regarding this issue, since some courts determine the systematic evasion of general company meetings starting already from two ignores [12]. In this regard, there is an urgent need for legislative regulation of this issue, since the recommendations from higher courts are not enough.

Judicial practice suggests that a kind of systematicity is also participating in general meetings of a legal entity visiting "every other time" [13]. Most likely, this is determined by the fact that the organization of economic activity requires a clear, well-established systematic regulation and prompt solution of the problems that arise for a particular legal entity.

Moreover, there is no uniform position in judicial practice on the issue of gross violation made by voting at all general meetings of a legal entity in a certain way. For example, such behavior of a particular participant (participants) can make it difficult to make decisions on key issues of the general meeting and impedes the implementation of economic activities.

Such position is only represented in the FAS recommendation document of the Volga region [14]. At the same time, the opinion that such measure, as the exclusion of a participant from the company membership, the application of which is related to unresolved disagreements, cannot be implemented if it is proved that the position of any member of the company and certain actions committed according to it were not indicated as knowingly false illegal representations [15]. 
Such position seems to be incorrect, since the exclusion of a participant in the courts is one of the few fixed ways to resolve a corporate conflict, and it is the court that has the authority to determine the validity of a particular position.

At the same time, civil law (clause 5, part 3, article 61 of the Civil Code of the Russian Federation) presumes one more way to resolve a deadlock. It is forcible liquidation a legal entity by the suit of the founder (participant) of this organization. It can be implemented in cases when it becomes impossible to achieve the goals defined for a legal entity with its charter documents without its implementation. It is also possible in cases when the activity of a legal entity becomes impossible or substantially hampered by circumstances that cannot be resolved otherwise.

Analysis of judicial practice confirms above-mentioned theoretical provisions. Thus, the court refused to satisfy the demand for liquidation, when the plaintiff could achieve a result, through voluntary withdrawal, which is identical to the forced liquidation initiated by him [16]. It seems fair that the courts advocate for the preservation of the legal entity and the stability of turnover, offering to resolve corporate conflicts in the least "painful" ways.

On the contrary, the courts satisfy the requirement of forced liquidation, when the company is only formally listed as a legal entity. It might not possess the necessary attributes due to insurmountable disagreements in the management of the company that impede the implementation of economic activity $[17,18]$. The correct position of the court is the one, according to which the relations of participants in the corporation should be personally trusting and contribute to achieving the goals, for which the company was founded. The relationships of the participants should not lead to conflicts regarding common business, since this cannot be considered normal business behavior.

The courts conclude that the liquidation is necessary in case of a prolonged corporate conflict between members of company having an equal number of shares (50\% each), since maintaining the company will inevitably lead to new legal disputes. In such conflicts, courts often appoint the liquidator of the arbitration manager from among the members of the selfregulatory organization $[19,20]$.

It seems that the criterion for the classification of corporate lawsuits is a substantive attribute. Corporate lawsuits are direct and indirect (derivative). The direct lawsuit protects the rights of the company itself. The plaintiff acts as a legal entity, indirect (derivative) claims contain a requirement for a member of the board of directors of the company, the sole executive body of the company, a member of the collegial executive body of the company and are filed in case of violating the rights of participants (members, shareholders, etc.) of this legal entity. At the same time, when considering indirect claims, the plaintiff (applicant) may pursue goals when the claim arises out of causing losses, the property rights of the organization itself are protected, and the plaintiff (applicant) protects its own interests, for example, for making profit, managing the company, etc.

\section{Conclusions}

We are convinced that the timely implementation of measures to resolve a corporate conflict by its parties and choosing the necessary and effective measure in a specific situation is the key to a successful resolution of the conflict without any losses, including time costs.

Deadlocks are also possible in public joint-stock companies; however, they are much less common due to the presence of a controlling stake or their predominant interest in a particular person.

In the case of a prolonged conflict, deadlock transforms into the final form, which does not allow the further development of economic activity and the only way out is to develop a business from scratch within the framework of another legal entity. 
Based on an analysis of the judicial practice of corporate disputes, somehow related to the appointment of a sole executive body and confirmation of its authority, it is recommended that the company approves a full package of internal documents (regulations on the board of directors, CEO, etc.). They detail the competence of management bodies, the procedure for convening meetings, maintaining protocols and making decisions. It is important to remember that the availability of such documents should be provided by the charter of the company.

An analysis of judicial practice allowed considering three ways to resolve the deadlock. At the same time, compulsory reorganization at the party's lawsuit could have been the least painful for both the business turnover itself and the company participants. It is advisable to prevent such situations from the beginning by amending parts 1, 2 of Article 50.1 of the Civil Code of the Russian Federation, as follows:

"1. A legal entity may be created on the basis of a decision of the founder (founders) on the establishment of a legal entity.

The number of founders should be odd.

2. In case of the establishment of a legal entity by one person, the decision on its establishment shall be taken solely by the founder.

In the case of the establishment of a legal entity by three or more founders, the specified decision shall be adopted unanimously by all founders."

Thus, a corporate conflict is an obvious or potential (hidden) conflict of interests (active or expressed in inaction). The participants of conflict are persons, whose interests conflict with the interests of a legal entity and (or) a participant (member, shareholder, contactor and etc.) of this legal entity on its own initiative or involuntarily and their protection is impossible without entering into a confrontation.

\section{References}

1. A.N. Levushkin, Zhurnal rossiiskogo prava 3, 47 - 55 (2016)

2. A.N. Levushkin, Grazhdanskoe pravo 2, 6 - 10 (2019)

3. I.V. Ershova, Lex russica 9, 46-61 (2016)

4. A.N. Levushkin, Zhurnal predprinimatelskogo i korporativnogo prava 3, 15-18 (2016)

5. A.N. Levushkin, E.V. Kosenko, Vestnik Permskogo universiteta. Iuridicheskie nauki 1, 73 - 83 (2017)

6. A.V. Gabov, O.V. Gutnikov, S.A. Sinitsyn, Iuridicheskie litsa v rossiiskom grazhdanskom prave: Monografiia. V 3 t. Obshchie polozheniia o iuridicheskikh litsakh» (tom 1) (M., INFRA-M, 2015)

7. Punkt 35 postanovleniia Plenuma Verkhovnogo Suda Rossiiskoi Federatsii ot 23.06.2015 No. 25 «O primenenii sudami nekotorykh polozhenii razdela I chasti pervoi Grazhdanskogo kodeksa Rossiiskoi Federatsii»

8. Postanovlenie 20AAS ot 16.07.2015 No. 20AP-3500/2015 po delu No. A62-7403/2014

9. A.N. Levushkin, P.A. Matveev, I.A. Tolstova, G.Y. Mitsyk, N.L. Avilova, International Journal of Recent Technology and Engineering (IJRTE) 8(4), 6085-6088 (2019)

10. Opredelenie Sudebnoi kollegii po ekonomicheskim sporam Verkhovnogo suda Rossiiskoi Federatsii ot 20.07.2015 No. 305-ES15-2706

11. Postanovlenie FAS Volgo-Viatskogo okruga ot 10.01.2008 po delu No. A4332220/2006-5-720; postanovlenie FAS Volgo-Viatskogo okruga ot 04.06.2007 po delu No. A43-19558/2006-5-368 
12. Postanovlenie FAS Zapadno-Sibirskogo okruga ot 21.03 .2012 po delu No. A4510224/2011; postanovlenie FAS Uralskogo okruga ot 11.08.2008 No. F09-5673/08-S4 po delu № A76-26298/2007-11-916/16; postanovlenie FAS Severo-Kavkazskogo okruga ot 06.04.2011 po delu No. A32-10769/2010

13. Postanovlenie FAS Severo-Zapadnogo okruga ot 24.05.2011 No. A56-13965/2010, postanovlenie FAS Dalnevostochnogo okruga ot 21.07.2014 No. F03-2960/2014 po delu No. A51-22498/2013

14. Rekomendatsii Nauchno-konsultativnogo soveta po voprosam primeneniia norm korporativnogo zakonodatelstva $i$ norm zakonodatelstva o nesostoiatelnosti (bankrotstve) (2010)

15. Informatsionnoe pismo Prezidiuma Vysshego arbitrazhnogo suda Rossiiskoi Federatsii ot 24.05.2012 No. 151

16. Postanovlenie AS Dalnevostochnogo okruga ot 23.05.2016 No. F03-2068/2016 po delu No. A24-2913/2015

17. Postanovlenie AS Zapadno-Sibirskogo okruga ot 23.12.2016 No. F04-5912/2016 po delu No. A45-7338/2016

18. Postanovlenie 20AAS ot 16.07.2015 No. 20AP-3500/2015 po delu No. A62-7403/2014

19. Postanovlenie Plenuma Verkhovnogo Suda Rossiiskoi Federatsii ot 23.06.2015 No. 25 «O primenenii sudami nekotorykh polozhenii razdela I chasti pervoi Grazhdanskogo kodeksa Rossiiskoi Federatsii»

20. Postanovlenie Arbitrazhnogo suda Zapadno-Sibirskogo okruga ot 01.09.2015 No. F04-20935/2015 po delu № A46-12003/2014 